\title{
Is There a British Film Industry?
}

\author{
Julian Petley
}

At first sight, Select Committee Reports may not appear to be the most interesting of reading. However, especially when taken together with their associated written and oral evidence, they are extremely useful for unearthing a great deal of useful data and prompting revealing discussions.

And so it is with the House of Commons Culture Media and Sport Committee's Report (House of Commons 2003a,b,c) which was the result of the question which the Committee posed in November 2002: 'Is there a British film industry?'

Thus, for example, we learn that in 2002 the British film industry brought in $£ 532$ million. The biggest contributors were 19 films made for the major Hollywood studios, which contributed $£ 234$ million; 42 indigenous features brought in $£ 165$ million; and 43 films shot abroad under co-production treaties $£ 133$ million. In the last five years UK films generated up to $£ 1.7$ billion in overseas and $£ 1.1$ billion in domestic investment.

These figures led the Committee to conclude that, although it would prefer the industry's main activity to be 'indigenous production of films about Britain, a substantial proportion of which break out to achieve success in the global market' (2003a: 3), it felt that: 
Attracting investment from overseas, especially in the US, is of vital importance to the sustainability of the British film industry by maintaining a throughput of large projects giving British talent and technicians the opportunity to practise their skills as well as remain within the industry (ibid: 35 ).

In 2002, total global spend on filmed entertainment was $\$ 63$ billion. Of this, $\$ 33.5$ billion was spent by North America and $\$ 15$ billion by Europe. The UK's share of this market was 5\% (including all British qualifying films). In 2001 UK film exports earned $£ 700$ million, and the balance of trade for film in the UK was positive by $£ 245$ million, the second highest figure since 1995.

Nonetheless, the DCMS memorandum to the Committee noted that: 'while the economic contribution of film is welcome, film is a relatively small industry compared to many others. The main reason for Government supporting film, therefore, is its cultural importance' (ibid: 10). Meanwhile, in 2002, twelve out of the 20 top-performing UK films were distributed by US-based companies. On the exhibition front that year, the UK had 3258 screens in 668 cinemas. 70 per cent were in multiplexes, with 5 per cent of the total dedicated to non-mainstream programming. US films (including co-productions with the UK and others) accounted for 49 per cent of releases and 91 per cent of box office revenues. UK films (including co-productions with the US and others) accounted for 21 per cent of releases and 24.4 per cent of box office. Without US co-productions, UK films accounted for fifteen per cent of releases and 6.2 per cent of revenues. 


\section{Tax breaks}

Given the success of the industry as an inward investment magnet, it was perhaps unsurprising that the Culture Secretary, Tessa Jowell, should have told the Committee that:

The role of Government is to set the right kind of regulatory environment and I think that through the structure of tax incentives, we have been successful in doing that and attracting substantial inward investment. The second, of course, is to make the UK an attractive place for companies to come and make films (2003b: 192).

At the time the Report was published, tax relief was currently available under Sections 42 and 48 of the Finance (No.2) Act 1992. The former accounted for 7-10\% of production budgets of films costing more than $£ 15$ million; the latter represented $12-14 \%$ of production budgets of films costing less, and was due to expire on 2 July 2005. The initial impact of these mechanisms has been the encouragement of the 'sale and leaseback' of a finished film; the lessor benefits from the tax break and the lessee receives an input of between $7-14 \%$ of production costs.

Over the past five years film-related tax relief has amounted to $£ 860$ million, and many other EU countries have similar arrangements. However, what Marc Samuelson and other producers argued before the Committee was that a permanent fiscal regime was needed in order to bring greater stability to film financing. Furthermore, they declared, Section 48 should be developed so as to help promote a distribution-led British film 
industry. Similarly David Elstein, in his capacity as Chair of the British Screen Advisory Council, argued that what was needed was a way of "tying the distribution function and its marketing sensibilities into production decisions by tailoring the tax breaks in such a way that you get the relationship going much earlier' (ibid: 81). And Samuelson pointed out that:

At the moment, the way that the value is assessed of a film is the production cost. It is simply what is spent on making the film, that is the value that can be used as part of the tax break. That is the value that the tax break is attached to. We are suggesting that partly instead of that the investment made by distributors would be the thing that attaches to the tax break or that attracts the tax break so that if, for example, half of the budget of a film was being invested by the distributors and sales agents, rather than the production being able to say "Right, we have got a film worth $£ 5$ million. We can now go and try and arrange some tax finance for that", actually the producer will be left with $£ 2.5$ million to find the tax break on but the distributor would have control of the $£ 2.5$ million that they were putting in. They would be able to raise a tax fund based on that. They would be able to have very much more influence over which films get made (ibid: 82).

The Committee concluded that:

It was absolutely clear to us that the current system of tax reliefs, while not solving the industry's problems, was of indispensable importance in maintaining a healthy throughput of large productions from overseas (with clear advantages for 
the domestic industry) and of equal importance in promoting a critical mass of indigenous film-making (2003a: 31).

It thus recommended that 'the Government commits to an evolution of Section 48 relief without further sunset provisions' (ibid: 34 ). More controversially, it also recommended, along the lines proposed by Sir Alan Parker in his controversial speech in November 2002, that the range of films eligible for tax relief should be broadened:

Given that one explicit aim of statutory arrangements (of which British qualification is a part) is to attract overseas productions to make films in the UK it is unavoidable, indeed perhaps desirable, that a number of qualifying films will have limited culturally-British credentials. We recommend that, in reviewing the tax regime for film production within the UK, the Government assesses whether there is a case for the introduction of new terminology to assist the classification of films according to country of origin distinguishing cultural content and financial provenance (ibid: 7).

\section{Cinema and Television}

If the Committee's deliberations illuminated the crucial importance of tax relief to the survival of the British film industry, they also sharply pointed up the declining role in its fortunes played by television ${ }^{1}$. Indeed, witness after witness identified as one of the industry's main difficulties a lack of support from UK broadcasters, as both producers and exhibitors These included the Film Council, Sir Alan Parker, the broadcasting union BECTU, Anthony Minghella, and Stewart Till, the Chief Executive of UIP and author of the DCMS Film Policy Review Group's report A Bigger Picture. 
Labour member Frank Doran estimated that British broadcasters contributed about $5 \%$ of total film spend to the film industry, of which $3.5 \%$ came from the BBC, and the Committee itself reported that the $\mathrm{BBC}$ and $\mathrm{C} 4$ each put around $£ 10$ million into films each year. This figure was described by Stewart Till as 'not an investment in British film production' (2002b: 152). Of all the films shown on the five main terrestrial channels in 2002, only 2.8 per cent were recent British ones.

The DCMS Memorandum to the Committee noted that: 'the Government believes that it is important that there is a close and effective working relationship between the British broadcasters and the film industry'. However, it also admits that this relationship is now much weaker than it was, and points out that Ofcom's review of public service broadcasting, which will take place no less than every five years, will include consideration of whether cultural activity in the UK and its diversity are 'reflected, supported and stimulated by the representation in those services (taken together) of drama, comedy and music, by the inclusion of feature film in those services, and by the treatment of other visual and performing arts'. Ofcom will not, however, be empowered to establish quotas or quantitative obligations for individual broadcasters to produce or broadcast feature films (ibid: 186).

In its Memorandum to the Committee, the Film Council (which lobbied the Government to back the amendment to the Communications Act 2003 requiring Ofcom to take into account feature film support when considering terrestrial broadcasters' 
compliance with their public service remit) actually quoted A Bigger Picture to the effect that:

The broadcasters are a vital and integral component of the British film industry. The Review Group is concerned that overall there is too great a mismatch between the benefits that the broadcasters reap from film - which accounts for $10 \%$ of TV viewing time - and the resources that they put back into film, whether through licensing of films or direct investment in production. If we are to develop a sustainable British film industry, there must be a steady stream of investment from such important and powerful end-users (ibid: 229).

And, in a Supplementary Memorandum, the Council argued that the Government's aim of a sustainable UK film industry 'can only be achieved with support from broadcasters'. They continued:

We believe that part of the broadcasters' public service remit is to make a contribution to the cultural vibrancy and diversity of the nation and its audiovisual industry. We believe they have an obligation to support the UK film industry because it is a key contributor to such vibrancy and diversity. The broadcasters already have very specific obligations in respect of, for example, independent television production, and regional production. Film should be no different. The broadcasters need to step up to the plate and deliver ... We believe that in order to fulfil the remit, an individual broadcaster should have to demonstrate that they are reflecting, supporting and stimulating film across several of the following activities; film development, film production, film 
acquisition, film distribution, film exhibition, film diversity and inclusion, film culture, film literacy/education, film promotion, and film training (ibid: 241).

Appearing before the Committee, Film Council Chief Executive John Woodward hammered the point home, stating that:

If the British film industry is struggling, and I would suggest that there is an industry but it is struggling, one of the key pieces of the value chain in the United Kingdom that is missing is input from television broadcasters in a way which is remarkably different to every other country in Europe ... Our hope and expectation is that going forward broadcasters will be asked to put a clear film policy on the table. I think it is the Film Council's intention that there is a right and proper role for British television broadcasters to play in working with the film industry but unfortunately we are in a position where they have not stepped up to the plate ... The piecemeal way which the finance of British films is put together means that key chunk of money that film distributors, financiers and producers would expect to derive from television in any other European country is missing in the United Kingdom and it is something that is debilitating and holding back the growth, not of inward investment ... [but] of indigenous British films. Yes, we think there is a serious problem there (ibid: 236).

Meanwhile Sir Alan Parker complained that: 'the statistics are quite alarming with regard to British films on both pay and free television in this country. The amount of investment in film is lamentable, lamentable is probably too nice a word' (ibid: 239). 
The Committee's recommendations on this matter were, perhaps unsurprisingly, pretty forthright. Stating that: 'We would like to see increased levels of support for film production and exhibition from the public service broadcasters', they added: 'We recommend that this be done in co-operation with the broadcasters in the first instance' (2003a: 45), thus clearly leaving the door open for possible statutory measures if the broadcasters failed to 'step up to the plate'. Noting that they would 'welcome support from BSkyB as a wise long-term investment in content which must be in that company's interests' (ibid), they then turned to the BBC, urging it 'to review its approach and level of commitment to feature film production, in consultation with the UK Film Council, given the significant comity of interests in this area' (ibid). They also expressed the hope that:

Ofcom will be able to take meaningful action to improve the relationship between the British film industry and the public service broadcasters to the benefit of the British people's enjoyment of, and access to, film. One avenue will be through the Statements of Programme Policy required from the broadcasters (ibid: 46).

\section{Elsewhere in Europe}

Finally, the Report sheds some interesting light on British attitudes towards continental European film policies. On the positive side, the Report notes that, in partnership with the Government, the Film Council is 'working with other state film bodies in Europe to strengthen links across the value chain, and to develop common policies where appropriate' (ibid: 27). 
A useful Annex (ibid: 76-7) gives details of various forms of government support of the film industry in France, Spain, Germany and Italy, which, inter alia, clearly shows how these governments actually require broadcasters to invest significantly in feature film production. Indeed, when the Report was written, Canal Plus was the largest player in feature films in France, where it invested 136 million Euros in 2001, and Frank Doran estimated that French broadcasters contributed around 37.5 per cent of total film spend, and Spanish ones 35.6 per cent.

Given his aversion to state support for film industries, a curious advocate of greater co-operation with Europe was even found in the figure of the late lamented Alexander Walker (here wrongly, if quaintly, referred to throughout as 'Mr Alexander'), who asked: You mention Hollywood; how many of you ladies and gentlemen have mentioned Europe? You say, Chairman, you have come back from Hollywood. I will be very interested indeed to hear what you found there, but I should have thought that the future of this film industry, if we can call it that, that we possess in this country lay in the continent of Europe, not in Hollywood, not on the West Coast of America. We cannot challenge that. It has been the abiding mirage that attracts people towards it over the decades, usually into bankruptcy and certainly into grave financial disappointment. We can never make a success of challenging the Americans. However, we can make a success, and indeed have, of combining our talents with the film production companies in Europe (ibid: 171). 
And yet, in spite of all the evidence put before them, which included the fact that, in France, French films have consistently enjoyed at least a 30-35 per cent market share, and without deigning even to mention the existence of MEDIA Plus and Eurimages (which Britain has still failed to re-join), the Committee concluded that:

Although a number of European Union countries do have extremely restrictive, protective measures for their indigenous production, there is no strong evidence that this has benefited their industries either financially or creatively (2000a: 29). This manages to be wrong on every single count: the measures are neither restrictive nor protective but, on the contrary, positive and pro-active, and their benefits are obvious to anyone walking past a cinema in, say, France. First of all, even in a small town, there actually is a cinema to walk past in the first place, and secondly, alongside the latest US releases (often playing there long before they reach the UK), one will nearly always find at least one French film. Had the Committee visited the west coast of France, as well as the west coast of America they might have discovered this elementary fact for themselves, and might even learned something from it. Unfortunately, however, the insular, anti-European attitudes excoriated elsewhere in this journal appear to have precluded both possibilities.

\section{Postscript}

It is, of course, arguable whether inward investment and tax relief schemes represent an effective way, in the long term, of protecting and encouraging indigenous film-making in Britain, especially if such schemes are used to help finance films which are 'British' only in a technical sense, or films which are produced simply and solely for the purposes of 
tax avoidance. However, as demonstrated by the first quote from the Report in this article, the Committee clearly felt that inward investment from Hollywood was the only way of sustaining a pool of British film-making talent which can then, presumably, afford to work on the occasional, relatively poorly paid, indigenous or 'cultural' film. However, the success, such as it is, of this kind of piecemeal, fiscally-based strategy - as opposed to the more thoroughgoing, systemic, structural measures preferred by the French in particular - is, to put it mildly, heavily dependent on all sorts of vagaries, such as the relative strengths of the pound and dollar (certainly a current worry), the attractiveness of other film-making locales (another headache, given the opening up of Eastern Europe), and, of course, the goodwill and co-operation of the Treasury and, in particular, the Inland Revenue.

A couple of weeks after I finished writing the above analysis of the DCMS Report, it was announced on February 10 that the Inland Revenue was cracking down, with immediate effect, on what it perceived as abuses of tax break schemes which, to put it at its simplest, have enabled investors to reduce their income tax liabilities by joining partnerships funding British films. Industry figures claimed that the change would remove at a stroke a third of the funding assumed to be available for new, and indeed current, productions. The first casualty was immediate: The Libertine, a film about the Earl of Rochester, starring Johnny Depp and John Malkovich, was cancelled just as shooting was about to commence; its US producer, Russ Smith, was quoted in the Financial Times, 12 February, as warning that: 'Britain will become a no-go area for film makers for years after this', and in the Independent, 25 February, as expressing 
bemusement that 'what was legal could be made illegal in a second'. Tom Stoppard's adaptation of Deborah Moggach's book Tulip Fever, starring Jude Law, was also put on hold. On February 15, in the Observer, Colin Vaines, head of European production for Miramax, stated that: 'this could be devastating for a lot of people in the British industry', and that the Hollywood majors would simply up sticks and take their productions to Canada, Germany or Hungary, where tax breaks were becoming more favourable. 40 films at various stages of production were thought to be in immediate threat, along with 230 jobs and $£ 250$ million in production volume.

\section{Notes}

1. It is indeed pretty sobering to compare the current situation with that of fifteen years ago, for an account of which see Petley (1989)

\section{References}

House of Commons Culture, Media and Sport Committee (2003a), The British Film Industry, Volume 1, London: The Stationery Office Limited. House of Commons Culture, Media and Sport Committee (2003b), The British Film Industry, Volume II, London: The Stationery Office Limited. House of Commons Culture, Media and Sport Committee (2003c), The British Film Industry, Volume III, London: The Stationery Office Limited. Petley, Julian (1989), 'Movie Money', in Sight and Sound, Summer 1989, pp. 152-7. 